\title{
Goat feeding system in Surat Thani Province, Thailand
}

\author{
Omanee S, Khamseekhiew B \\ Faculty of Science and Industrial Technology, Prince of Songkla University, SuratThani Campus \\ PO Box 8 Khunthalay Post office, Amphur Mueang, SuratThani Province 84100, Thailand \\ sutha1055@gmail.com
}

\begin{abstract}
The purpose of this research was to study feeding system of goats farming in Surat Thani Province (SRT), Thailand. The data were collected from all selected farmers using a questionnaire. The samples were 62 farmers in SRT and carried out during March to December 2015 including 10 districts. The population of goats was 1,913 heads. Most of the goat farmer was in Punpin districts. Farmers use their own family members as labor to manage the farm. Natural grown locally roughage is the staple feed for goats. Farmers raised their goats by feeding them with native grasses, leucaena forage and fresh oil palm frond. Concentrate was highly used $(88.6 \%)$ including soybean peel, palm kernel cake $(48.6 \%)$ and commercial feed $(42.9 \%)$. Oil palm decanter cake is preferable agro-byproducts used by the farmers. It can be concluded that SRT has a great potential as the hub for goat production in the south of Thailand for the local and external consumptions due to its abundant in natural feed resources.
\end{abstract}

Key Words: Farm, Feeding System, Goat, Surat Thani Province

\section{INTRODUCTION}

Goats are associated with the lives of Muslims in Thailand. The goat assembled in religious ceremonies such as the welcoming a newborn baby. The goat farmers mainly aim to household consumption. The goats can be raising together with the planting crops such as rubber and oil palm plantations. Goat has ability to adapt well with the various environmental conditions, climatic conditions and have several advantages compared with ruminants such as cattle and buffalo. Goat pregnancy is shorter only 150 days and mostly with twin kids. Goats have high digestibility of crude fibre and have good production even on poor quality roughages. In mixed crop and livestock farming systems, goat manure is used as compost fertilizer to keep soil productive. The population of goat in Thailand is approximately 468,377 heads (Department of Livestock Development 2015), in which $94.0 \%$ are found in the South of Thailand.

Goat production in Surat Thani province (SRT) is increasing because of the high internal and external demands by the consumers. The price of meat goats is between 100 to 150 bath per $\mathrm{kg}$ live weight. In general, the single most cost in livestock operation is feed cost. Any management practice that can reduce feed cost will significantly improve profit of goats farming. However, feed resources, feeding system, availability of feed resources and raising practices are important aspects when planning for sustainable feeding systems in SRT. The board objective of this study therefore, was to determine the feed and feeding system as generate under goat farm condition in SRT, Thailand.

\section{MATERIAL AND METHODS}

The survey was carried out during March to December 2015 in Surat Thani Province (SRT) south of Thailand including the following 10 districts: Chai Buri, Kanchanadit, Tha Chana, Ban Na San, Mueang Surat Thani, PhunPhin, Don Sak, Khian Sa, Chai Ya, and Tha Chang by randomly selected to gather information from goat's farmers. The selection 
of farmers was done according to their interest and readiness to corporate with the researchers. The total numbers of respondents were 62 farmers.

The data were collected from all selected farmers using a questionnaire. The questionnaire consisted of the following sections: general information, types of raising, herd size, feed and feeding system, types of feed, sources of roughage and concentrate, amount of roughage and concentrate for goats per day, the use of silage on a farm, use of agro-byproducts in the farm and feed supplements used

\section{RESULTS AND DISCUSSION}

General information: Goats in all surveyed sites in the SRT was belonging to the head of the family. Total number of goat surveyed were 1,913 heads, the highest population of goats in Chai Buri district was 400 heads. And the smallest number of goats in Tha Chang district was 60 heads. The highest density of goat farms was in Phun Phin districts.

Table 1. Population of goats and number of the goat's farmers in Surat Thani province in 2015

\begin{tabular}{lccc}
\hline \hline \multirow{2}{*}{ Districts } & \multicolumn{2}{c}{ No of goats } & \multirow{2}{*}{ No of farmers } \\
\cline { 2 - 3 } & $($ Heads $)$ & (Percentage) & 1 \\
\hline Chai Buri & 400 & 20.9 & 12 \\
Kanchanadit & 338 & 17.7 & 4 \\
Tha Chana & 245 & 12.8 & 8 \\
Ban Na San & 230 & 12.0 & 11 \\
Mueang & 171 & 8.9 & 13 \\
PhunPhin & 168 & 8.8 & 4 \\
Don Sak & 153 & 8.0 & 2 \\
Khian Sa & 80 & 4.2 & 6 \\
Chai ya & 68 & 3.6 & 1 \\
Tha Chang & 60 & 3.1 & 62 \\
\hline Total & 1,913 & 100.0 & \\
\hline
\end{tabular}

Farmer characteristics presented in Table 2. Most of the farmers use their own household labor to manage the farm. They raised meat goat as their second occupation except for large farms where run the farm as a main business. Most of them were Buddhist $62.9 \%$ and Muslim is minority.

Types of raising system: Intensive system was prominent in SRT whereas $51.6 \%$ of the farmer raised goats in housing. During night time all goats are housing. Only $8 \%$ of farmers raised goats in extensive system or allows their goats to free graze on the fields. However, these animals sometime fed in other peoples land which could create serious problems between neighborhood.

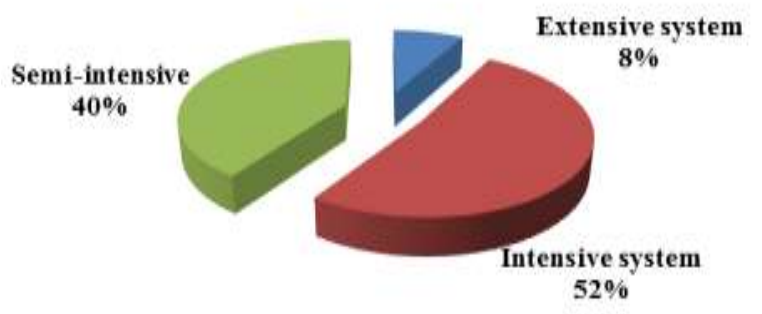

Figure 1. Type of goat farming systems raising in Surat Thani Province, Thailand 
Table 2. The characteristics of goat's farmers in Surat Thani Province, Thailand

\begin{tabular}{lcc}
\hline \hline Charateristics of farmer & Numbers & Percentage \\
\hline Experiences of the farmers (years) & & \\
$1-3$ & 32 & 51.6 \\
$4-8$ & 18 & 29.0 \\
More then 8 & 12 & 19.4 \\
Religion & & \\
$\quad$ Muslim & 23 & 37.1 \\
Buddhist & 39 & 62.9 \\
Labor & & \\
Family's members & 57 & 91.9 \\
Employees & 2 & 3.2 \\
Family + employees & 3 & 4.8 \\
\hline
\end{tabular}

\section{Goat feeding strategies and feed availability}

Sources of roughage and concentrate feeds used for goats in SRT are presented in Table 3. Roughage used is locally available grown mainly a staple feed. Oil palm fronds (OPF), leucaena forage and grasses used were 90.3, 80.6 and 58.1\% respectively. Most of the farmers using concentrate $(56.5 \%)$ and roughage $(100 \%)$. In the past, farmers raising their goats by feeding with natural grasses, leucaena forage and fresh oil palm leaves. Most farmers were introduced the used of agro-byproducts such as oil palm decanter cake, soybean peel and palm kernel cake (PKC). Currently, $74.2 \%$ of farmer used this agrobyproduct as usual supplement. The reasons why the farmers adopted the above agrobyproduct because it available in local and to reduce the production cost. Some farmers cut leucaena forage in the morning and given in fresh every day for their livestock. The daily amount of roughage for goats was not certain depends on feed obtain. Ninety percent of the farmer used fresh OPF for feeding goat. An oil palm frond was obtained during harvesting or pruning of palms trees. The leaves contain a higher percentage of crude protein $(\mathrm{CP})$ than the petioles. Farmer fed OPF about 1 frond per 2 goats basis. Most of the farmers use soy bean peel, followed by PKC and commercial feed, 88.6, 48.6 and $42.9 \%$ respectively. The use of contentrate in goat's farm was due to easily purchased. PKC can be classified as an energy feed and its chemical composition is similar to that of copra meal, rice bran or corn gluten. In SRT, most of the farmer used PKC for goats as supplementary feeding. In addition, most of farmers lack of information on the nutrient requirements of goats. Results from the survey shows that some of the farmers making grass silage. This may due to the small holder farm lack of instruments such as chopping mechine.

There were many problems in meat goat raising in SRT, Thailand. These problems including lack of roughage diet in dry season, unsolved animal health, disease and parasitism, limited available of good does and buck to improve the breeds, lack of knowledge of management systems and the market still inconsistent. 
Table 3. Feeds used for the goats farms in Surat Thani Province Thailand

\begin{tabular}{lcc}
\hline \hline Feed sources & No. of farms & (Percentage) \\
\hline Roughages & 62 & 100.0 \\
Concentrate & 35 & 56.5 \\
Agro-byproducts & 46 & 74.2 \\
Sources of roughage & & \\
Grasses & 36 & 58.1 \\
Oil palm fronds & 56 & 90.3 \\
Weeds & 30 & 48.4 \\
Leucaena forage & 50 & 80.6 \\
Others & 35 & 56.4 \\
Use of concentrates & & \\
Commercial feed (CP 14\%) & 15 & 42.9 \\
Soybean peel & 31 & 88.6 \\
Palm kernel cake & 17 & 48.6 \\
\hline
\end{tabular}

\section{CONCLUSION}

Goat's farming is not a main occupation to the farmers in Surat Thani. More strategic feeding system during dry season should be improved and proper management practices should be introduced. To disseminate the farmers on good management practices, feed and feeding systems and feed preservation for stock in dry season should also be implemented.

\section{REFERENCES}

Department of Livestock Development (DLD). 2013. Yearly Statistics Report 2013. Ministry of Agricultural and Cooperative. [cited on December 1, 2015]. Available from: http://www.dld.go.th/ict/th/index.php?option=com_content\& view=section\&id=45\&Itemid=12 $3)$.

Department of Livestock Development. 2015. The Number of lamb and goat separate by number of livestock and number of farmer. Bangkok (Thailand): Information Technology Center. 